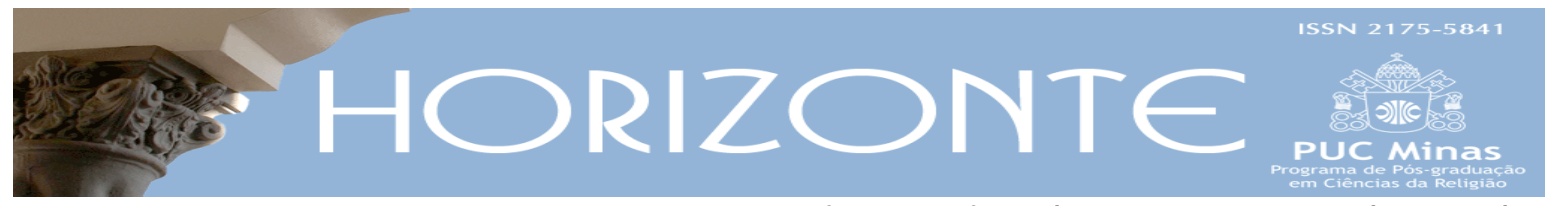

Dossier: Gender and Religion- Original Article (@) $\odot \Theta \Theta$

DOI - 10.5752/P.2175-5841.2015v13n39p1427

\title{
Women leadership in the Mosque
}

\author{
Líderes femininas na Mesquita
}

Jolanda Guardi*

\begin{abstract}
Starting from the Friday woman lead prayer held in 2005 in New York, I focus in this paper on the role Muslim contemporary women play in shaping Muslim societies and communities to assert their authoritative role "in the mosque". I begin by setting the scene of the event and, after a brief discussion of its symbolic meaning, I address two main questions: first, how the debate which followed the event contributed and contributes to promote a change inside the Muslim world and outside it, letting emerge some leading figures in the struggle for justice and equity in contemporary Islam; and second which are the theological and legal basis for the role of woman as imāma (prayer leader). Although the issue of women leadership in prayer is far from finding a unanimous consent, the debate demonstrates that some issues can and must be discussed, and that a change is possible only when Muslim women question the male elite power.
\end{abstract}

Keywords: gender ğihād, Qur'ānic hermeneutics, women imāma, women leadership, leadership in the mosque.

\section{Resumo}

Este artigo tem como ponto de partida uma oração liderada por uma mulher em 2005, na cidade de Nova York. O texto foca no papel desempenhado pelas muheres muçulmanas atuais no sentido de preparar a comunidade e a sociedade mulçumana e de buscar a afirmação de sua autoridade "na mesquita". Inicialmente dfine-se o local do evento e, depois de uma breve discussão sobre seu significado simbólico, abordam-se duas questões principais: em primeiro lugar, a forma como o debate que se seguiu ao evento contribuiu e contribui para promover uma mudança dentro do mundo muçulmano e fora dele, deixando emergir algumas figuras de destaque na luta pela justiça e equidade no Islã contemporâneo; em seguida, quais são as bases teológicas e jurídicas que justificam o papel da mulher como imã (líder de oração). Embora a questão da liderança das mulheres na oração não possui um consenso unanimidade, o debate demonstra que algumas questões podem e devem ser discutidas, e que a mudança só é possível quando as mulheres muçulmanas questionarem o poder da elite masculina.

Palavras-chave: jihad gênero, hermenêutica corânica, imãs femininas, lideranças femininas, liderança na mesquita.

Article received on April 15, 2015 and approved on September 28, 2015.

* Doctor in Arabic Language and Literature. Research fellow at the Universitat Rovira i Virgili, Tarragona, Spain. Country of origin: Spain. E-mail: jolanda.guardi@mail.com. 


\section{Introduction}

The completion of this book with its discussions on multiple aspects and experiences inside the gender jihad is a clear indication that the roles I have played in this struggle are neither limited to this one symbolic act nor concluded by performing this act. To many people, worldwide, I am only known through sensationalized controversies. That is understandable. I hope they will eventually come to understand that sensationalist responses to certain public actions are not the basis of, and never can be the goal of, my identity quest as a female in Islam. (WADUD, 2006, p. 247).

On March 18, 2005 Amina Wadud, a scholar of Islamic studies at Virginia University and a Muslim, led a mixed-gender Friday prayer in New York. Although this was not the first time such an event happened, the fact that it was in New York and that it was preceded by a press conference gave the event a significant media coverage and an echo in the whole Muslim world and beyond that largely overcame the expectations. Since that date, in fact, an extensive debate is ongoing in the Muslim world, discussing the possibility, for a woman, to be a leader in her community. As underlined in the above-quoted paragraph, the event was one among others Wadud undertook in her struggle for gender justice in Islām. Starting from this event, in this paper I will address two main issues: first, the fact that the 2005's "performance" (HAMMER, 2010, p. 92) achieved the goal of opening a debate, not only about the role of women's leadership in the Muslim community, but also about the concept of authority, and paved the way for Western scholarly studies about Muslim women and their role in Arab-Muslim societies too; second, that it gave start to a legal debate internal to Muslim law, which begun with the several fatwa ${ }^{1}$ delivered after the event and questioning the possibility for Muslim women to lead prayer. This episode, moreover, although started in the United States and apparently did not affect the Arab world, helped on the contrary in the spread of the movement for equity in these regions too.

\footnotetext{
${ }^{1}$ Authoritative legal opinion given by a muftī (legar scholar) in response to a question posed by an individual or a court of law. A fatwa is tipically requested in cases not covered by the juridical literature and is neither binding nor enforceable.
} 


\section{Authority, Leadership, and the Role of Muslim Women}

In the above-mentioned occasion, women were at the core of a religious ritual; not only, in fact, Wadud led the prayer, she also offered the congregation the hutba $a^{2}$ and it was a woman too, who performed the ad $\bar{a} n .^{3}$ As for how it was organized, this prayer was an event in the sense that a lot of media representatives attended it, and that outside the space where the prayer was performed 4 there were a lot of Muslims protesting against such an innovative initiative. In the following days too, the media attention focused on the first female-led congregational prayer and "in the first two weeks following the prayer, the requests flowed in with other responses to the prayer at a rate of about fifty a day" (WADUD, 2006, p. 248). The negative responses called for the unity of the Muslim world against what was considered a fitna; 5 the main argument was that, disregarding what was a 1400 years tradition would create dissension and chaos (AHMED and SILVERS, 2010, p. 143-145). On the contrary

[Almost ten] years have passed; and in spite of the fears expressed at the time, the Muslim community has not been torn by dissention and unrest. The prayer, as galvanizing as it was, did not turn the world upside down for Muslims. Rather, it forced and inspired a fruitful discussion on the nature of a woman's place in the mosque that continues to this day. (AHMED; SILVERS, 2010, p. 143)

The public will to exert religious authority by women is a characteristic of the twentieth-century Muslim world. However, this does not mean that in the past women did not have access to knowledge nor did rule or speakke and debate about religious issues (NADWI, 2007). Nor that Wadud was the first Muslim woman to

\footnotetext{
${ }^{2}$ The huțba (خطبة), literally "discourse", is a sermon usually held by the imām, during the Friday congregational prayer. Apart from its spiritual content, it has always had also a strong political value, and it was and is the occasion to express opinions and give directions about social issues in general. Therefore the symbolic value of Wadud's huța.

${ }^{3}$ The adān (أذان) is the call for prayer uttered by the mu'addin (muezzin).

${ }^{4}$ The prayer took place in the Synod House of the Cathedral of St. John the Divine, the church of the Episcopal Diocese of New York, as no mosque in the New York area has agreed in hosting the event.

${ }^{5}$ The word fitna literally means trial or testing, temptation; by extension, treachery, persecution, seduction, enchantment, or disorder resulting from these things. In modern political terminology, allegation of fitna ca be used to discredit the actions of opponents.
}

Horizonte, Belo Horizonte, v. 13, n. 39, p.1427-1449, July/Sept. 2015 - ISSN 2175-5841 
lead a prayer (WADUD, 2006). Women, in fact, have led prayer since the time of Prophet Muhammad, and although not all legal schools agree, in mixed-gendered congregations too. The difference being that, for the first time, the 'ulama's authority was challenged in public. That is to say, other actors have emerged in the Muslim community, who claim for themselves the right to speak in the field of religion (KRÄMER; SCHMIDTKE, 2006, p. 12).

It is then noteworthy to notice the impact the event had in the Muslim world in the whole. First, the debate on women's issue opened up in the United States and in the western Muslim world in general, where especially Muslim women of European origin felt being a Muslim as a step back in relation to social rights women obtained after a long struggle (this is, of course, my reading). Second, it opened up a debate internal to the Muslim women's movement and groups with very different view about religion and the role of woman in the community which led to bring together Muslim women from all over the world, who decided to undertake practical action together in particular sectors, as for example equality in the family. ${ }^{7}$ As a result, in Western and Arab world there was a significant change in the role of women in the mosque notwithstanding the contrary opinions regarding women leading prayer. These late were extensively delivered and published from the year in question and till today (LAURY, 2013) from imām of different schools and nationality. In the Arab world, changes happened in some Arab countries. Although as conclusion of a long process it is precisely in 2005, for instance, that Mohammed VI King of Morocco appoints 104 women to religious councils (BANO; KALMBACH 2012, p. 59-84), and that initiatives including women preachers take place in Saudi Arabia (Ibi, pp. 105-126). In the meantime, academic (women)scholars interest themselves in women issues in the religious field, till then disregarded in favour of the study of secular women's associations or

\footnotetext{
${ }^{6}$ The 'ulamā' are those who have been trained in religious sciences. In the classical age they were formulators of Islamic theology and law. In the modern era, their sphere of operation is confined to the mosque and the madrasa (here: school of religious sciences). As imām of the local mosque, the 'álim leads daily prayers, delivers the Friday sermon, and teaches children the basics of Islamic law and Qur'ānic recitation. On occasion of birth, death, and marriage, he may also be called upon for prayers or for help in performing the rituals themselves. In rural area, the 'âlim may be the most educated or wisest man in the area, but not necessarily formally trained; in urban centres, 'ulamä' generally posses some sort of credentials or formal education. (ESPOSITO, 2006, sub voce).

${ }^{7}$ This is the main objective of Musawah Project "global movement for equality and justice in the Muslim family" (www.musawah.org) founded by Indonesian Sisters in Islam (www.sistersinislam.org).
} 
organizations and some interesting studies are published (for instance CALDERINI, 2009; HADDAD and ESPOSITO, 2010; BANO and KALMBACH, 2012; ASLAN, HERNANDEZ, and MEDENI, 2013; SADEGHI, 2013; KATZ, 2014). The debate focuses on who has the right to interpret religious texts and give directions to the believers in their everyday life. In other words, the 'ulamā', traditionally male - and who historically played significant roles in the political field too as they were often bound with the political power - had to confront female scholars and in general female believers who struggled and struggle to promote an active role of women in religious affairs.

As Islamic authority founds itself on the single scholar knowledge of Islām, the first goal is to demonstrate to have acquired this knowledge, in order to become assertive. Classic authority is a male authority and more than explain or interpret God's rule Muslim (male)jurists assimilated social norms into the šarī $a$ :

Islamic law has been regarded as the embodiment of Divine justice. In order for Muslims to attain the divine scale of justice they must implement these norms of justice in their everyday life. [...] The Muslim jurists, by exercise of their rational faculty to its utmost degree, recorded their reactions to the experiences of the community: they created, rather than discovered, God's law. What they created was a literary expression of their aspirations, their consensual interests, and their achievements; what they provided for Islamic society was an ideal, a symbol, a conscience, and a principle of order and identity (SACHEDINA, 1999, p. 29).

The dilemma Muslim women face then, is to struggle for their rights while maintaining their religious - and often cultural - identity. This is the reason why a debate around ethical issues started even before a fight for social and political rights in the Muslim context. 


\section{The text...}

All religions are open to different readings; the first step was then in the case of Islam too, to propose a different interpretation of the Qur'ān. However, offering new readings is not enough, it is also necessary to establish the legitimacy of each new reading starting from the text itself. A fundamental assumption of all new interpretations is therefore that no change will take place in Muslim societies if its legitimacy does not come from the Qur'ān. The central idea is that the text is polysemous, that is, open to different interpretations. This statement comes from the Qur'ān itself: “Those who listen to the saying of the Quran and follow the fairer of it. Those are the ones whom God guided, and those are the ones imbued with intuition. (sūrat az-zumar, 18). ${ }^{8}$

Thus the text itself tells us that better readings than others exist, but leaves to find them to the humankind. The readings proposed by women, break with a tradition that requires men to interpret the sacred text; these women are believers, that is, they do not question the fact that the Qur'ān is the word of God. Only within this context the feminine reading makes sense and can be disseminated (ANWAR, 1996). Women's hermeneutics therefore, looks in the Qur'ān to find confirmation of the equality of the sexes, believing that this late has been hidden by male exegetes, who have compiled tafsī 9 from a patriarchal point of view. Again, the Qur'ān itself affirms the equality between man and woman in different verses as, for example, sūrat al-ḥuğarāt, 13

O humanity! Truly, we created you from a male and a female and made you into peoples and types that you recognize one another. Truly, the most generous of you with God is the most devout. Truly, God is Knowing, Aware.

\footnotetext{
${ }^{8}$ All quotes are taken from THE SUBLIME QURAN, 2007.

${ }^{9}$ Qur'ānic exegesis. Elucidation, explanation, interpretation, and commentary carried out in order to understand the Qur'ān and its commandments. Tafsir is carried out in linguistic, juristic, and theological fields.
} 
Ontologically, all human beings are equal and are distinguished from each other exclusively on the basis of their practice of the Qur'ānic principle of equity. Therefore there is no contradiction between being Muslim and the struggle for women's rights, the goal being the pursuit of a fairer gender system. In addition to making a distinction between universal principles contained in the Qur'ān (RAHMAN, 1996) and principles connected with the contingent situation of the society in which the revelation occurred, this hermeneutics works by re-reading controversial verses from the women's point of view, always referring to those verses that declare unequivocally the equality between man and woman and, at the same time, emphasizing the context.

If, then, the readings proposed up to recent times have been patriarchal, it is necessary not only to study the relation between hermeneutics and history, but also the contents of the knowledge and methods through which the legal system has been generated. The basic concept is that no theory of sovereignty of man over woman is compatible with the doctrine of tawhìd (Oneness of God), ${ }^{10}$ because God is one. This concept allows Muslim women exegetes to classify any reading that puts man on a higher plane than woman as theologically incorrect. Moreover, a reading of the sacred text that also suggests subtle parallels between God and men in their capacity as fathers and martyrs of Islām is rejected. To quote Mary Daly in her Beyond God the Father (1973), to call God "father" is to call fathers God. As Sartar Aziz recalls: "I'm deeply grateful for the fact that my first idea of god was formed by Islam, because I've been able to think of the divine as something completely without sex or race and therefore completely 'a-patriarchal'”(CLEARY; AZIZ, 2000, p. 47).

Although the range of leadership roles filled by women in contemporary Muslim societies and communities is wide, and explains differences in influence

\footnotetext{
${ }^{10}$ Tawhìd is the defining doctrine of Islam. It declares absolute monotheism - the unity and uniqueness of God as creator and sustainer of the universe. Used by Islamic reformers as an orginizing principle for human society and the basis of religious knowledge, history, metaphysics, aesthetics, and ethics, as well as social, economic, and world order (ESPOSITO, 2006, p. 317). Amina Wadud too refers to a "tawhidic paradigm" in order to affirm that woman and man are on the same level in respect to God (WADUD, 1992).
} 
and impact on those societies and communities, it remains the fact that, in my opinion, from a theoretical point of view the most fruitful path to follow is women hermeneutics. Women theologians have a long history in Islam, as we know from biographical dictionaries and historical sources: faqìha, mutafaqqiha, 'âlima, and muftiya are known and respected scholars (ABOU-BAKR, 2003, p. 307). Tradition informs us that the first woman to be a faqih ha (expert in Islamic law) was 'Ā'iša, the young wife of the Prophet. She was consulted on a number of unclear issues after Muhammad's death, and classical hadīt collections commonly contain a section devoted to her. She is considered to have established the rules for critical sunna (tradition) analysis. That is, she compared the sunna in light of the Holy Qur'ān and checked what the Prophet's Companions said, correcting mistakes (see for instance KABBANI and BAKHTIAR, 1998; NADWI, 2007). In any case, although in a general way, all references agree that it was the Prophet who encouraged women to play an active role in the community, there is no evidence of Qur'ānic commentaries written by women until modern times, and even then, modern female exegetes associate themselves only with Qur'ānic hermeneutics relating to women's issues. It is important to stress that modern and contemporary faqiha commit themselves to commenting only on those sections of the text that relate to the role of woman in Islām and Muslim societies.

One of the first to engage herself in tafsīr was 'Ā'iša 'Abd ar-Raḥmān (19131998), also known by her pen name Bint aš-Šāțî. She published more than sixty works, including literary criticism, exegesis, novels, biographies, and articles in journals and newspapers; about forty of them are devoted to the Qur'ān and Islamic studies. The author proposes these works for a better understanding of woman's emancipation from the point of view of Muslim culture. 'Abd ar-Rahmān states that this work is necessary to revise the issue of Muslim women's rights. As she states, liberation

for the new [Muslim] woman does not mean equity, because that woman does not confuse [this concept] with the natural biological differences between man and woman, nor with the social differences between them. For this new woman, equity does not go beyond equal rights and duties ('ABD AR-RAHMAN, 1967, p. 10). 
This restricted idea of liberation leads 'Abd ar-Raḥmān to write in the same text that the question of Qur'ānic equity is only referring to good and evil and does not concern masculine and feminine. She then tries to maintain the text neutrally as far as gender is concerned; an attitude shared by other contemporary faqīha. For the most part, this issue remains in the background, as she devotes herself to the analysis of Qur'ānic chapters that do not discuss gender issues. Her standpoint is also in some way at odds with more recent academic studies, whose focus is placed on demonstrating that equality of the sexes is instituted in the Qur'ān and necessary for a Muslim society to achieve justice ('adl). In any case, 'Abd arRaḥmān remains the first woman who devoted herself to Qur'ānic interpretation in modern times and contributed also to shape the hermeneutic discourse in the context of human rights.

Contemporary female scholars share some common ideas, but nonetheless each of them represents an original approach. Perhaps the most well known of them, inside and outside the Muslim community, is the already quoted Amina Wadud, who proposes a gender-inclusive reading of the Qur'ān (i.e., a reading whereby gender is a legitimate category for interpretation). She defines herself as a Muslim feminist theologian (GUARDI and BEDENDO, 2012, pp. 125-129) and refers to Simone de Beauvoir to explain what is "feminist" in Islamic feminism stating: "Feminism is a radical notion which turns women first of all into human beings" (WADUD, 2006, 76). Wadud presented her reading of the sacred text in her most famous study, Qur'an and Woman (1999), in which she discusses, among other issues, what she calls the "tawhidic paradigm." She considers tawhìd more than the "oneness" of God. Tawhìd is, in her reading, the agentive principle of equilibrium and cosmic harmony. After this first book, in 2006 she published Inside the Gender Jihad: Women's Reform in Islam. Here she shifts from theory to practice. Starting from textual exegesis, she, in fact, becomes more involved in pursuing a practical goal, namely equity in the Islamic family (see note n. 7). 
A different point of view is presented by the Moroccan Asma Lamrabet, who believes that nowadays the approach mentioned above is contributing toward the institutionalization of what she terms "phantom-Islam". According to her view, this non-existing Islam shapes an imagery of Muslims that corresponds merely to Western projections. Therefore, Lamrabet criticizes discourses on Islam that consider woman's status as being the same everywhere without taking into consideration local differences and socioeconomic contexts that exist in different Muslim countries. This attitude, affirms Lamrabet (2003), corresponds to colonialism. The author uses a very direct language, starting from the following principle: the Qur'ānic message is first and foremost a message underpinned by justice and equity. Furthermore, any discrimination based on religion, sex, or any other criteria would amount to a clear contradiction of the Qur'ān's core spiritual message. She pushes her thought so far as to claim that Muhammad is one of feminism's universal representatives. Lamrabet divides Qur'ānic verses into two broad categories: those that have a universal meaning and those (a minority) that are bound to their initial historical context, affirming that the two must not be confused if we intend to remain faithful to the text. If the Qur'ān is a liberating book for women, then it is necessary to answer the following question: Why did women not have any influence on the development of Muslim civilization? Lamrabet answers this question by referring to the jurist Ibn Hağr, who identifies roughly 300 women who taught Islamic science in the third century of the hiğra (LAMRABET, no date).

It thus follows that women's exclusion is limited to the sphere of politics because from a given time onward they did not participate any longer in the development of religious sciences. Lamrabet makes her position very clear, affirming that

by re-reading the scriptures and re-evaluating historical data women and men have come to realize that there is no justification for this subordination of women, which is done in opposition to the message of Islam. However, we have realized that the majority of the interpretations of Islam are neither divine Will's manifestations, nor those of a wholly defined social system; rather they are human fabrications that, with time, 
have become the base of Islamic thought. The fundamental problem lies in a rigid exegesis that was compiled centuries ago and displays a pathetic literalism, especially when it concerns women. Even though the text itself offers extremely important respire so that each social reality can adapt its reading, generations of scholars slid into the same immutable and outdated readings out of a fear of not being true to their predecessors, considered as 'infallible' (LAMRABET, no date, p. 4).

One of the most interesting women intellectuals of the contemporary era, the Pakistani Asma Barlas, starts from a different approach analyzing the Qur'ân. In fact, she tends to read it as an a patriarchal text and is committed to demonstrating the link between Qur'ānic hermeneutics and Muslim woman's liberation. She also thinks that the Qur'ān can be re-read in a wider sense as an instrument to promote democracy even outside the Muslim world. Muslims may have to read the Qur'ân as a liberating and a patriarchal text, and this reading is not bound to the reader's gender. Barlas states that the ontological knowledge of religion is not preexisting; on the contrary, this is a social construction created at a given historical time according to a particular methodology and specific historical meaning. This also happens where religion manifests itself as a tool for oppression and sexual difference. That said, she analyzes the meaning of patriarchate from both a religious and nonreligious point of view. If, on the one side, patriarchate means a patriarchal vision of God as father and, therefore, the supremacy of male over female progeny, on the other patriarchate defines itself in secular terms as a policy of sexual difference that gives prominence to men, "transforming the biological sex in politicized gender" (BARLAS, 2005, p. 98). Barlas's reading differs insofar as she reads the Qur'ân in the whole to extract teachings on God's definition, human beings' creation, ontology, sexuality, family, and relationships between the spouses. From this reading, she demonstrates that both the text and its hermeneutics are not patriarchal.

A political scientist, Barlas also encourages Muslims to take an active role in the community in which they live, especially in non-Muslim societies. She believes in fact that Muslims can positively contribute to developing societies with 
particular attention to the concept of democracy and representation because Islām promotes them.

Regarding classical hermeneutics, the women mentioned above engineer a gender $\breve{g}$ ihâd (i.e., they develop a particular discourse that is feminine and also critical, political, and interdisciplinary). The proposed exegesis is also a linguistic act because it is a social practice that contrasts the dominant discourse on Islām. This undertaking matters in relation not only to the non-Muslim cultural fields, but also to the interreligious discourse where political power, religion, and economy jointly operate against women.

\section{3 ... and the Critic}

Besides the Qur'ān, the other kind of texts where women's critic is central is the hadīt corpus. In the case of women leading prayer, these are especially important as the Qur'ān does not permit nor forbid the possibility of women imāma. As stated above, several female and male legal scholars and muftī delivered fatwa relating to the issue with different interpretations. ${ }^{11}$ In what follows I will present what is at stake and suggest some topics for discussion. However, for the purpose of this paper "it is less important whether a hadìt is literally true $[\ldots]$ then that it was held to be authoritative by scholars" (KATZ, 2014, location 223-225).

The prophetic tradition quoted and discussed by every scholar - though read in different ways - is one regarding Umm Waraka bint Nawfal, 12 reported in several versions in the canonical hadit's collections and commentaries. I quote some of them: ${ }^{13}$

\footnotetext{
${ }^{11}$ For a survey of the responses to the Wadud prayer see LIVING ISLAM, 2005.

${ }^{12}$ For a complete survey of the works where this tradition is quoted see JALAJEL, 2013.

${ }^{13}$ I omit the chain of transmitters - in round brackets in the Arabic text - in the English translation.
} 
1.

$$
\begin{aligned}
& \text { (أخبرنا الفضل بن دُكَيْن حدثنا الوليد بن عبد الله بن جُمَيْع قال: حدثني جدتي) عن أم ورقة بنت } \\
& \text { عبد الله بن الحارث وكان رسول الله يزورها ويسميها الشهيدة وكانت قد جمعت القرآن وكان رسول } \\
& \text { الله حين غزا بدراً قالت له: تأذن لي فأخرج معك أدواى جرحاكم وأمرّض مرضاكم لعل الله يهدي } \\
& \text { لي شهادة. قال: إن الله مهدٍ لك شهادة. فكانت يسميها الشهيدة. وكان النبي صلى الله عليه وسلم } \\
& \text { قد أمرها أن تَؤمّ أهل دارها وكان لها مؤذن وكانت تؤم أهل دارها [...]. . وقال عمر صدق رسول } \\
& \text { الله كان يقول: انطلقوا بنا نزور الشهيدة. }
\end{aligned}
$$

1. The Messenger of God used to visit her [Umm Waraka] and to call her the martyr. She knew the whole Qur'an. And when the Messenger of God went to conquer Badr, she said to him: Give me your permission so that I go with you, I will heal your wounded people and your ill ones and maybe God will bestow me with martyrdom. He said: "God will bestow martyrdom upon you. He called her the she-martyr". The Prophet - peace be upon him - ordered her to act as imāma for the people of her $d \bar{a} r$, and she had a muezzin and she led the prayer for the people of her $d \bar{a} r$ [...] The Prophet used to say: let's go visit the (she)martyr. (IBN SA'D, 2001, vol. 10, p. 424)

2.

$$
\begin{aligned}
& \text { (عن ابي نعيم قال حدثنا الوليد قال حدثني) عن أمّ ورقة بنت عبد الله بن الحارث الأنصاري وكانت } \\
& \text { قد جمعت القرآن وكان النبي صلى الله عليه وعلى آله وصحبه وسلّم قد أمرها أن تؤمّم أهل دارها وكان } \\
& \text { لها مؤذّن وكانت تؤمّ أهل داره. }
\end{aligned}
$$

2. Ummm Waraka knew the Qur'ān and the Prophet - may be peace and blessing of God be upon him and upon his family and his companions ordered her to act as imāma for the people of her dār, and she had a muezzin and so she was the imāma of the people of her $d \bar{a} r$. (AL-BANNĀ, no date, v. 5, p. 223).

After this text, Al-Bannā writes a commentary in which he recalls the different opinions and interpretations, stating that in this hadìt the issue is to establish if a woman can lead prayer in her house if there are men. He discusses the "differences" among the scholars and then affirms: 


$$
\begin{aligned}
& \text { وفيها أيضا دليل على جواز إمامة المرأة بمثلها كما في حديث أم ورقة رضي الله عنها والظاهرة أها }
\end{aligned}
$$

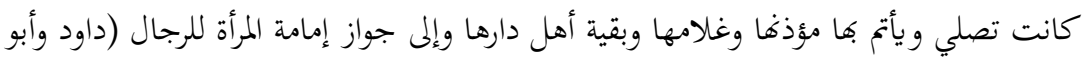

$$
\begin{aligned}
& \text { ثور والمزني والطبري) }
\end{aligned}
$$

There is also evidence of the permissibility of a woman leading men in prayer [...] as the evidence is that she [Umm Waraka] prayed and she led her muezzin, her servant, and the other people of her house and for the permissibility of woman conducting prayer before men are Dawūd, Abū Tawr, al-Mazunī and aț-Ṭabarī (Ibi, p. 224).

As the author reports and as it is reported in other sources then, it seems that some classical scholars agreed in permitting the role of imāma to women. This opinion is reported by An-Nawawī too in his Kitāb al-mağmū' (no date), where, after discussing another hadìt regarding the validity of man's prayer when he is behind a woman or a hermaphrodite, he comments:

$$
\text { وقال البيخ ثور والمزني وابن جرير: تصح صلاة الرجال وراءها، حكاه عنه القاضي ابو الطيب العبدرى مذهب الفقهاء كافة أنه تصح صلاة الرجال وراءها إلا أبا ثور والله أعلم }
$$

Abū Tawr, al-Mazunī and Ibn Ğarīr said: "The prayer of men behind her [the woman] is valid". So said the judge Abū aț-Ṭayb al-'Abdarī. Abū Hâmid said: "Scholars agree: Abū Tawr is the only one who considers valid the prayer of a man behind her [the woman]. God knows better" (AN-NAWAWİ, no date, v. 4, p. 151-152).

Unfortunately, we can rely only on Al-Bannā's and an-Nawawī’s words, as no survived work of these authors - where available - reports their opinion on this issue. 
3.

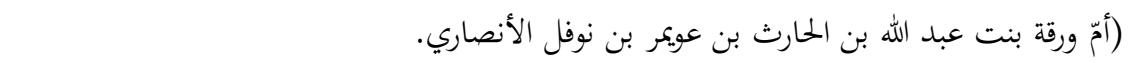

ويقال لها أم ورقة بنت نوفل فنسبت إلى جدّها الأعلى.

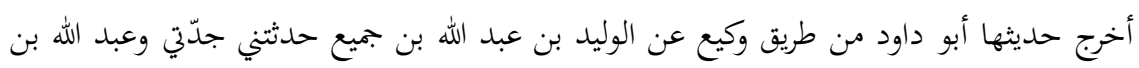

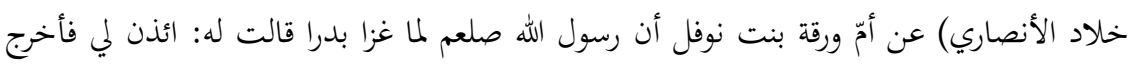

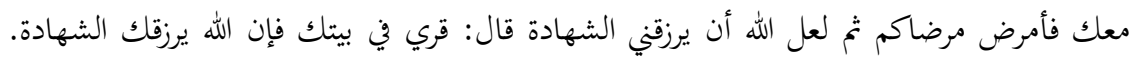

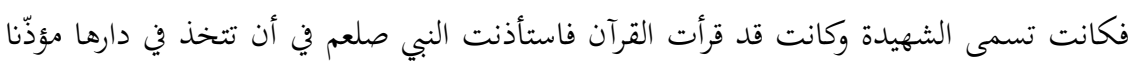

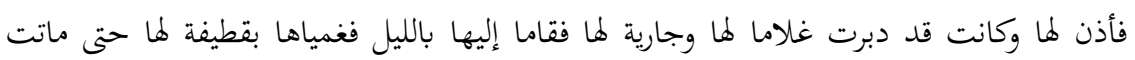

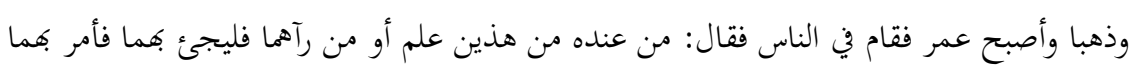

$$
\text { فصلبا فكانا أول مصلوب بالمدينة. }
$$

(ومن طريق محمد بن فضيل عن الوليد عن [عبد] الرحمن بن خلاد عن أم ورقة بنت عبيد الله بن

$$
\text { الحارث بهذا والأول أتم. }
$$

وأخرجه ابن السكن عن طريق محمد بن فضيل ولفظه) أفها قالت: يا رسول الله لو أذنت لي فغزوت

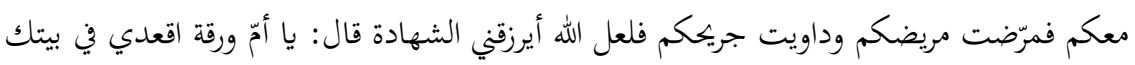

فإن الله سيهدي إليك شهادة في بيتك. وكان رسول الله صلعم يزورها في بيتها وجعل لها مؤذّنا لها.

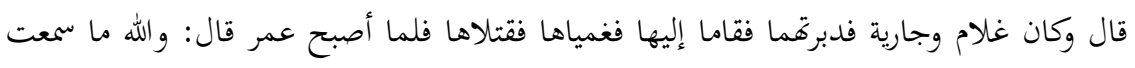

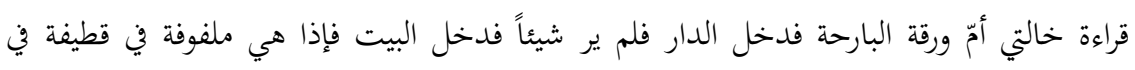

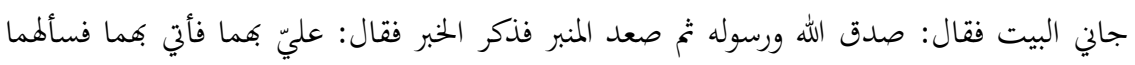

فأقرا أغما قتلاها فأمر بهما فصلبا.

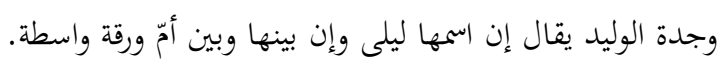

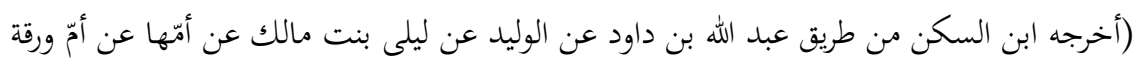

$$
\text { وهو عند ابن منده بعلو عن عبد الله بن داود. }
$$

وكذا قيل بين عبد الرحمن بن خلاد وأمّ ورقة واسطة.

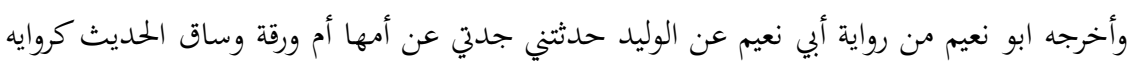

3. [...] When the Messenger of God - may be the peace and blessing of God be upon him - went out in the battle of Badr Umm Waraka told him: Give me permission to go with you and I will nurse your ill ones and maybe God will give me martyrdom. He said: stay at home God will give you martyrdom. She was called the (she)martyr. She recited the Qur'ān, and the Prophet gave her permission to have a muezzin in her house who call for her the adāan. She had at disposal a boy and a girl, they came one

Horizonte, Belo Horizonte, v. 13, n. 39, p.1427-1449, July/Sept. 2015 - ISSN 2175-5841 
night and suffocated her with a velvet cloth until she died, then they went away. 'Umar got up and said to the people: Who knows about them or saw them? He catched them, sentenced them and let them be crucified, and this was the first crucifixion in Madina. [the second half of the text repeats the same story from another narrator till the murder of Umm Waraka, then states:] When 'Umar got up he said: By God, I did not hear the recitation of Umm Waraka yesterday; he went to her $d \bar{a} r$ but did not see anything; then he entered the house (bayt) and he saw her laying down enveloped in a piece of cloth in a corner. He said: God and His Messenger said the truth, then he climbed on the minbar, spread the news and said: Go, take them to me, question them; they confessed having killed her and he ordered them to be crucified. [...] (AL'ASQALĀNİ, 2011, p. 2044)

4 .

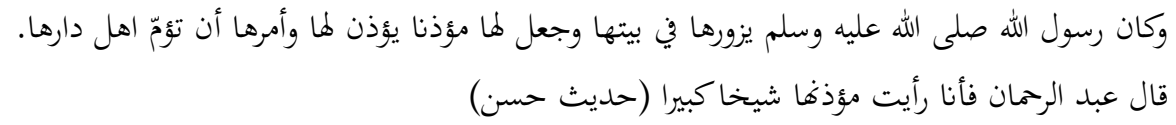

4. The Prophet of God - may be the peace and blessing of God be upon him - used to visit her in her house and appointed for her a muezzin to call for the prayer and ordered her to lead the prayer for the people of her dār. 'Abd ar-Raḥmān said: I saw him and he was very old (Ḥadīt sound) (ABŪ DAWŪD, 2002, v. 3, p. 144).

The discussion of the text focuses first of all around the word $d \bar{a} r$, which can be translated as "home" but also "region, territory, locality" (REDA, no date; JALAJEL, 2013) and, among those who consider it sound, about if the congregation is intended as a mix- or only women one. Regarding the first issue, both men and women have delivered several fatwa. Against women leading prayer are the majority of imām from all over the Muslim world, with slightly different reasons but highly different tones. Hina Azam (2005), for instance, professor of Islamic Studies at the University of Texas, states that although she agrees with seeking gender equity, and with the need of a revision of the classical Islamic legal methodology, she is very critic regarding the method adopted. As she affirms, the "right" way to propose a new reading must 
a) explain why the existing methodology is unacceptable (that is, why it necessarily leads to conclusions that are makru or haram), and b) provide an alternate methodology that is more capable than the existing one at discerning the divine intent (AZAM, 2005, p. 2).

This and other critics rely on the fact that it is not possible to question the method classical exegetes built up. Moreover, the problem is to discern between the method and the methodology, i. e. the critic of the theoretical frame in which the method is encompassed. From this perspective, the re-reading of the hadīt proceeds from different epistemological premises and, therefore, adopts a different approach. This is what, in my opinion, critics of this reading fail to understand.

The hadīt of Umm Waraka does not provide per se a sufficient basis for women leading congregational prayer. The fact that some consider it sound and some not, however, opens possibilities for a different reading.

The text by Al-'Asqalānī, moreover, in the second half, offers a distinction between the word $d \bar{a} r$ and the word bayt. If the author feels the need to distinguish among the two, this means that they have a different meaning. ${ }^{14} \mathrm{~A}$ point of discussion could maybe be the fact that in the quoted narration at some point 'Umar affirms not having heard Umm Waraka's qirā'a the day before. From the other narrations we know Umm Waraka ğama'at al-Qur'ān, which is to say, she knew the whole text. From the hadìt reported by Al-'Asqalānī it seems then that Umm Waraka recited every day the Qur'ān and that this recitation was heard even outside her house (outside because 'Umar "went to her $d \bar{a} r$ "). This could, in my opinion, be a good starting point to discuss the possibility for women to lead prayer, as it seems that she addressed her reciting not only to the people of her house, but also to people outside it.

\footnotetext{
${ }^{14}$ The word bayt can also simplly mean "room" but, as in the whole preceding part of the text is intended as house, home, this means that $d \bar{a} r$ has a wider meaning, as for example a group of houses.
} 
The text reported by Abū Dawūd introduces another possible question; in fact, it is said, the Prophet "ordered her" to lead the prayer and appointed a muezzin for her. The question here could be why she needed a muezzin if she had to lead only the people of her house as the role of the muezzin is to be heard at least in a whole neighborhood. The ambiguity remains in another classical reference, the one reported in Al-Mas' $\bar{u}$ dì Murūğ ad-dahab (The Meadows of Gold, 2005) where the author speaks of Gazāla imra'at Šabīb, who was very brave and fought in battle with men. When she arrived in Kufa

$$
\text { وقد كانت غزالة نذرت أن تدخل مسجد الكوفة فتصلي فيه ركعتين تقرأ فيها سورة البقرة وآل }
$$

She entered Kufa's mosque and did two rak'a there reciting sürat albaqara and sūrat $\bar{A} l$ 'Imrān, then seventy men entered the mosque and prayed there the midday prayer; she came out having obtained what she wanted (AL-MAS' $\overline{\mathrm{U}} \overline{\mathrm{I}}$, 2005, v. 3, p. 117).

The narration leaves unexplained if when the men entered she left or not (in Arabic the connector $w a$-binds the two phrases; $w a$ - is a coordination mark, so it could be read as she remained in the mosque with the men, also because the two sūra the text refers to are the longest ones in the Qur'ān). In any case, it was not a Friday prayer, but a prayer performed in an unusual circumstance.

Let alone the debate about the authenticity of these texts, the discussion must be inserted in a wider frame, which deals with the fact that the obligation to lead prayer is addressed only to men:

But it is problematic to argue that the state of address, in this case, is to men alone. We argue, as with other ritual obligations, the obligation to lead is by default inclusive of women. The default case may only be changed if the Prophet explicitly commands it. There is no such genderspecific command to lead the prayer in the Qur'an, nor does the Prophet himself explicitly state that only men may lead the prayer. Thus the default prayer leadership must be considered inclusion and women's unrestricted prayer leadership must be permitted (AHMED and SILVERS, 2010, p. 167). 
Be as it may, the discussion around the Prophet's traditions opens anew a never ended debate about the authenticity of the traditions themselves; as several women and male scholars argue - both Muslims and not Muslims - the entire apparatus has to be viewed with a critical perspective, as they are a human collected corpus and not the word of God. The collections, in this perspective, served to convey political and ideological view depending on the legal school of thought or the struggle for religious knowledge hegemony:

My own view is that the controversial nature of the methodologies and beliefs of the ashab al-sunna is well enough established that we have to view the hadith apparatus skeptically, as well as the hadith themselves. The claims that the hadith reliably record the Prophet's deeds, that the methodologies used to establish their reliability are convincing, and even that the Prophet's acts are normative and should be recorded were all at one time controversial; the hadith-science edifice that Islamicists regard with intimidated awe in part conceals the hadith's polemical functions. Ibn Sad's Tabaqat work, for instance, does not disinterestedly report the activities of early Muslims; it argues and attempts to demonstrate that Muslims of the first generations were doing what the mythology of the pristine early community requires them to have been doing: recording hadith and transmitting it, asking each other about precedents, and reproaching those who disregarded this authentic religious knowledge. (REINHARDT, 2010, no page).

\section{Concluding remarks}

From what precedes, it is possible to come to some conclusions. First, as I explained, the performance of Wadud had a high symbolic value, namely claiming a more active role in religious affairs for women. This includes the presence of women in the mosque: not only as imāma, but also as protagonists of the spiritual life; that is the possibility for Muslim women to make decisions about themselves and their role in the community. In this sense, the Wadud performance started a fecund debate about the possibility for women to assert their authority and to challenge an authority, which in Islām historically refers to men only. 
The debate around women leading prayer is part of a wider debate about the presence of women in the mosques, an issue about which an enormous literature is available for the pre-modern and modern period, and which is a "hot" issue in contemporary times too (KATZ, 2014). Giving women access to the mosque means giving them the possibility to challenge the patriarchal power, and this has more to do with barely prosaic issues than religious ones.

This debate is still ongoing, of course, and it sees the opposition between ideas and strategies not only among Muslim women and men, but also among nonMuslim women and men scholars about the treatment of Islamic medieval sources, about if and how to acknowledge soundness to Prophetic traditions and other fundamental issues. (REDA, 2004; MELCHERT, 2006; KATZ, 2014). When Muslim women engage in the hermeneutic of the sacred text, they break a new ground as interpreters of their tradition, not only regarding the content of this new interpretation, but also with regard to the method applied, which is far from a legal and/or a juridical historical one, but instead moves towards interdisciplinarity and transactionality. This is in my opinion what all critics, Muslim and Western scholars, fail to understand: the issue is not to give a "true" reading (a typical patriarchal attitude) but to propose other readings which have the same right to be performed as the traditional ones, in line with the Muslim hermeneutic tradition. That is to say, to manifold the possible readings of the text among which the she/he believer can choice, and by doing so, to widespread this new "Muslima theology" (ASLAN, HERNANDEZ, and MEDENI, 2013).

\section{REFERENCES}

(In what follows I only quote the first name of women scholars consciously)

'ABD AR-RAḤMĀN, ‘Ā'iša. Al-mafhūm al-islamī li-taḥrīr al-mar'a. Al- Hูurṭūm: Ğami'at Umm Durmān, 1967.

ABOU-BARK, Omaima. Teaching the Words of the Prophet: Women Instructors of the Hadith (Fourteenth and Fifteenth Centuries). Hawwa. Journal of Women of the

Middle East and the Islamic World. France ,v. 1, n. 3, p. 306-328. 2003. 
ABŪ DĀWUD. Șạ̣ị̣̣ sunan Abī Dāwud. Al-Kuwayt: Mu'assasat Garās li-n-našr wa-ttawzī', v.7, 2002.

AHMED, Elewa and SILVERS, Laury. "I am one of the people": A survey and analysis of legal arguments on woman-led prayer in Islam. Journal of Law and Religion. St. Paul, v. 26, n. 1, p. 141-171, 2010.

ANWAR, Ghazala. Riflessioni femministe musulmane. Concilium, Roma, v.1, p. 85-95, 1996.

ASLAN, Ednan; HERNANDEZ, Marcia; MEDENI, Elif. (ed.). Muslima Theology. The Voices of Muslim Women Theologians. Frankfurt am Main: Peter Lang, 2013.

ASQALĀNĪ(AL-). Al-iṣ̣̣āba fĩ tamīyz aṣ-ṣaḥāba. Bayrūt: Al-maktaba al-'aṣariyya, 2011.

AZAM, Hina. A critique of the argument for woman-led Friday prayers. 18 mar. 2005. Available at:

<http://www.islamawareness.net/Deviant/Progressives/critique.html>. Accessed 13 feb. 2015 .

BAKHTIAR, Laleh (translation by). The Sublime Quran. Chicago: Kazi Publications, 2007.

BANNĀ(AL-). Al-fatḥ ar-rabbānī. Bayrūt: Dār Ihyā’’ at-turāt al-‘arab̄̄, v. 18 , no date.

BANO, Masooda ; KALMBACH, Hilary. (ed.). Women, Leadership, and Mosques. Leiden, Boston: Brill, 2012.

BARLAS, Asma. Globalizing Equality: Muslim Women, Theology, and Feminisms. In : NOURAIE-SIMONE, Fereshteh. On Shifting Ground: Muslim women in the global era. New York: Feminist Press, 2005. p. 91-110.

CALDERINI, Simonetta. Contestualizing Arguments about Female Ritual Leadership (Women Imāms) in Classical Islamic Sources. Comparative Islamic Studies.

Denmark, v. 5, n. 1, p. 5-32, 2009.

CLEARY, T. and AZIZ, Sartar. (ed.). Twilight Goddess: Spiritual Feminism and Feminine Spiritualism. Boston: Shambala, 2000.

DALY, Mary. Beyond the God Father. Toward a Philosophy of Women's Liberation. Boston: Beacon Press, 1973.

GUARDI, Jolanda; BEDENDO, Renata. Teólogas, musulmanas, feministas. Madrid: Narcea ediciones, 2012 .

HADDAD, Yvonne \& ESPOSITO, J. L. Daughters of Abraham: Feminist Thought in Judaism, Christianity, and Islam. Gainesville: University Press of Florida, 2010. 
HAMMER, Juliane. Performing gender justice: the 2005 woman-led prayer in new York. Contemporary Islam. Germany, v. 91, n. 4, p. 91-116, 2010.

HAMMER, Juliane. Identity, Authority, and Activism: American Muslim Women approach the Qur'ān. The Muslim World, USA, v. 98, p. 443-464, 2008.

IBN SA'D. Kitāb aṭ-ṭabaqāt al-kabīr. v.11 . Al-qāhira: Maktabat al-ḩāniğ̄ì, 2001.

JALAJEL, D. S. Women and Leadership in Islam: A Critical Analysis of Classical Islamic Legal Texts. 2013. Dissertation (Ph. D.)- University of the Western Cape, Bellville, 2013.

KABBANI, M. H. \& BAKHTIAR, Laleh. Encyclopedia of Muhammad's Women Companions and the Traditions they related. Chicago: Kazi Publications, 1998.

KATZ, Marion Holmes. Women in the Mosque. A History of Legal Thought and Social Practice. New York Chichester: Columbia University Press, 2014. Kindle Edition.

KRÄMER, Gudrun and SCHMIDTKE, Sabine. (ed.). Speaking for Islam. Religious Authorities in Muslim Societies. Leiden; Boston: Brill, 2006.

LAMRABET, Asma. When Women Appropriate the Sources. No date. Available at: $<$ http://www.asma-

lamrabet.com/Articles/en/When\%2oWomen\%20appropriate\%20the\%20Sources.pdf>. Accessed 20 feb, 2015.

LAURY. Shaykh Ali Gomaa approves of woman-led prayer. 5 Oct. 2013. Available at: <http://jumacircle.com/shaykh-ali-gomaa-approves-of-woman-led-prayer/> . Accessed 13 feb. 2015 .

LIVING ISLAM. A Collection of Fatwas and Legal Opinion on the Issue of Women Leading Prayers. 19 mar. 2005. Available at: <http://mac.abc.se/home/m9783/ir/d/fwlp_e.pdf>. Accessed 22 feb. 2015.

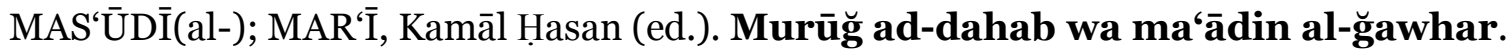
Bayrūt: Al-maktaba al-'așariyya, v.5, 2005.

MELCHERT, Christopher. Weather to keep Women out of the Mosque: A Survey of Medieval Islamic Law. In: MICHALAK-PIKULSKA, B. and PIKULSKI, A. Authority, Privacy and Public Order in Islam. Leuven; Paris; Dudley: Uitgeverij Peeters en Departement Oosterse Studies, 2006, p. 59-69.

NADWI, M. A. Al-Muhaddithat: the women scholars in Islam. Oxford London: Interface Publications, 2007.

NAWAWĪ(al-). Kitāb al-mă̌mū'‘ Šarh al-mahadab li-š-širāzī. Ğadda: Maktabat aliršadāt, v.23, no date. 
RAHMAN, F. Islam Origins and Ideals. In: BARAZANGI, Nimat Hafez; ZAMAN, M. R.;AFZAL, O. Islamic Identity and the Struggle for Justice. Gainesville: University Press of Florida, 1996, p. 11-18.

REDA, Nevin. Women leading congregational prayers. Available at: $<$ ccmw.com/wp-content/uploads/2014/o4/women_leadership1.pdf $>$. Accessed 10 feb. 2015 .

REINHART, A. K. Juynbolliana, gradualism, the Big Bang, and hadith study in the twentyfirst century. The Free Library. 01 jul 2010. Available at:

<http://www.thefreelibrary.com/Juynbolliana, gradualism, the Big Bang, and hadith study in the...-a0260285823>. Accessed 22 feb. 2015.

SACHEDINA, A. The ideal and the real in Islamic law. In: KHARE, R. S. (ed.). Perspectives on Islamic Law, Justice, and Society. New York: Rowman \& Littlefield 1999, p. 15-32.

SADEGHI, B. The Logic of Law Making in Islam. Women and Prayer in the Legal Tradition. Cambridge: Cambridge University Press, 2013. Kindle Edition.

WADUD, Amina. Qur'an and Woman. Rereading the Sacred Text from a Woman's perspective. New York: Oxford University Press, 1999.

WADUD, Amina. Inside the Gender Jihad: Women's reform in Islam. Oxford: Oneworld, 2006. 